\title{
PAIN IN WORKERS WITH SHOULDER IMPINGEMENT SYNDROME: AN ASSESSMENT USING THE DASH AND MCGILL PAIN QUESTIONNAIRES
}

\author{
Camargo PR ${ }^{1}$, Haik MN ${ }^{1}$, Filho RB ${ }^{2}$, Mattiello-Rosa SM ${ }^{1}$ e Salvini TF ${ }^{1}$ \\ ${ }^{1}$ Departamento de Fisioterapia, Universidade Federal de São Carlos, São Carlos, SP - Brasil \\ ${ }^{2}$ Clínica FOCUS, São Carlos, SP - Brasil \\ Correspondence to: Tania F. Salvini, Departamento de Fisioterapia, Universidade Federal de São Carlos, Rodovia \\ Washington Luis, km 235, CEP 13565-905, São Carlos, SP - Brasil, e-mail: tania@power.ufscar.br
}

Recebido: 04/12/2006 - Revisado: 21/02/2007 - Aceito: 23/02/2007

\begin{abstract}
Objective: This study assessed physical function and pain in male and female workers with shoulder impingement syndrome using the Brazilian Portuguese versions of the Disabilities of the Arm, Shoulder and Hand (DASH) and McGill pain questionnaires. Methods: Twenty-seven assembly line workers (18 men and 9 women; mean age of $33.26 \pm 6.49$ years) in the school supply industry were evaluated. The duration of the shoulder impingement pain was $31.74 \pm 32.92$ months and the amount of time of the workers in this industry was $11.08 \pm 6.41$ years. The DASH questionnaire was used to evaluate functional status and symptoms of the upper limbs of the workers. Using the McGill Pain Questionnaire, the pain was quantified by the number of words chosen and by the pain rating index $(\mathrm{PRI})$. Results: The women presented higher scores $(\mathrm{P}<0.05)$ than the men for both DASH overall and DASH work scores. The women chose more words $(17.00 \pm 2.59)$ than the men $(13.33 \pm 3.16)$ and also presented the highest total PRI $(\mathrm{P}<0.05)$. Conclusions: The results obtained in this group of Brazilian workers with shoulder impingement identify the most commonly used descriptors of shoulder pain. Further, this study shows that females are more likely than males to refer physical disability and pain. Also, the DASH and McGill pain questionnaires are important and helpful tools in the clinical evaluation of shoulder impingement syndrome.
\end{abstract}

Key words: soreness, rotator cuff, overhead activity, Portuguese language.

\section{RESUMO}

\section{Dor em trabalhadores portadores da síndrome do impacto do ombro: uma avaliação através dos questionários DASH e McGill de dor}

Objetivo: Este estudo avaliou função física e dor em trabalhadores com síndrome do impacto através das versões brasileiras dos questionários "Disabilities of the Arm, Shoulder and Hand” (DASH) e McGill de dor. Método: Vinte e sete trabalhadores (18 homens e 9 mulheres; idade média de 33,26 \pm 6,49 anos) de uma linha de produção de uma indústria de material escolar foram avaliados. O tempo de duração de dor no ombro era de 31,74 \pm 32,92 meses e o tempo de trabalho na indústria era de 11,08 \pm 6,41 anos. O questionário DASH foi utilizado para avaliar o estado funcional e os sintomas dos membros superiores dos trabalhadores. Através do questionário McGill de dor, a dor foi quantificada pelo número de palavras escolhidas e pelo índice de classificação da dor (ICD). Resultados: As mulheres apresentaram maiores escores $(\mathrm{P}<0,05)$ que os homens para ambos os módulos do DASH. As mulheres escolheram mais palavras $(17,00 \pm 2,59)$ que os homens $(13,33 \pm 3,16)$ e também apresentaram o maior ICD total $(\mathrm{P}<0,05)$. Conclusão: Os resultados obtidos neste grupo de trabalhadores brasileiros com síndrome do impacto do ombro identificam os mais comuns descritores utilizados para dor no ombro. Além disso, este estudo mostra que as mulheres estão mais propensas a relatarem incapacidade física e dor quando comparadas aos homens. Os questionários DASH e McGill de dor são ferramentas importantes e úteis na avaliação clínica da síndrome do impacto do ombro.

Palavras-chave: dor, manguito rotador, atividade acima da cabeça, língua portuguesa. 


\section{INTRODUCTION}

The term "impingement” was introduced by Neer in $1972^{1}$. Shoulder impingement is one of the most common causes of shoulder pain and has a high socioeconomic impact due to its influence on working ability². "Impingement” usually refers to pain in the anterosuperior region of the shoulder ${ }^{3}$. The pain occurs because of compression and mechanical abrasion of the subacromial structures against the anterior undersurface of the acromion and coracoacromial ligament, especially during elevation of the $\mathrm{arm}^{3}$.

Many questionnaires have been used to evaluate functional status and pain in people with shoulder disorders, and to assess the influence of these shoulder disorders on the daily activities of these people $e^{4,5}$. The relationship between upper limb disorders and work is a common problem in many countries. Shoulder pain or specific disorders such as shoulder impingement syndrome are especially frequent among workers in various industrial plants ${ }^{6}$. Questionnaires provide an easy means for evaluating the effectiveness of rehabilitation protocols and surgical techniques ${ }^{7,8}$.

It is important to measure individuals' own experience of disability using self-reported questionnaires, especially those that measure specific health parameters such as physical function and pain. The Disabilities of the Arm, Shoulder and Hand (DASH) questionnaire was developed to measure physical disabilities and symptoms relating to a wide variety of upper limb disorders ${ }^{9}$. Subsequently, this questionnaire was translated into Brazilian Portuguese and culturally adapted ${ }^{10}$. It was found to be a reliable and valid instrument for upper limb assessments on Brazilian subjects.

One of the most widely known and used verbal pain assessment tools is the McGill pain questionnaire (MPQ). This questionnaire was developed by Melzack in $1975^{11}$, and it evaluates painful experiences both qualitatively and quantitatively. Subsequent to its development, it has been translated into many different languages, including Portuguese $^{12}$. Castro translated the MPQ into Brazilian Portuguese with some cultural adaptations ${ }^{13}$.

The National Social Security Institute of Brazil has shown that work-related musculoskeletal disorders account for more than $80 \%$ of the diagnoses that resulted in work accident assistance or disability retirement ${ }^{14}$. Among these disorders is shoulder impingement. Despite this, there are no studies that evaluate how Brazilian workers describe the disability and pain associated with shoulder impingement.

Thus, the purpose of this study was to assess physical function and pain in a group of workers with shoulder impingement syndrome using the Brazilian Portuguese versions of the $\mathrm{DASH}^{10}$ and $\mathrm{McGill}^{13}$ pain questionnaires. Possible gender differences were also evaluated. To our knowledge, this is the first study to identify the disabilities in a group of Brazilian workers with shoulder impingement, as well as the Portuguese words that best describe this kind of pain.

\section{METHODS}

\section{Subjects}

The target population for this study was assembly line workers with regular exposure to repetitive overhead working conditions that require great physical effort. A total of 214 assembly line workers (79 men and 135 women) from the same sector in the school supply industry were initially recruited and evaluated. Thirty-five workers (20 men and 15 women) were diagnosed with shoulder impingement. Of the 20 men, two did not meet the inclusion criteria because they had partial-thickness supraspinatus muscle tear, as seen on ultrasound imaging. Of the 15 women, 6 did not complete the questionnaires because of work scheduling or personal problems. Therefore, twenty-seven workers (33.26 \pm 6.49 years) were assessed in this study. Eighteen of them were male (31.28 \pm 6.35 years) and 9 were female (37.22 \pm 4.97 years). The duration of the shoulder pain was $31.74 \pm 32.92$ months, as reported by the workers, and the average time of the workers in the industry was $11.08 \pm 6.41$ years.

The clinical diagnosis of shoulder impingement was made using the clinical criteria for pain reproduction from at least 3 of the following tests: Neer ${ }^{1}$, Hawkins ${ }^{15}$, Jobe ${ }^{16}$, Speed $^{17}$, Gerber ${ }^{18}$ and Yergason ${ }^{19}$. Ultrasonography was also performed on both the involved and the uninvolved shoulders, in order to confirm the diagnosis. All of the subjects had Neer's stages I and II unilateral shoulder impingement ${ }^{20}$. The side involved was the dominant one in 14 subjects and the nondominant one in 13 subjects. Subjects who were pregnant or had histories of shoulder injury, torn tendons, ligamentous laxity, previous shoulder or neck surgery, or systemic illnesses, were excluded. Further, subjects who were unable to read and understand Portuguese were excluded. This project was approved by the National Health Council (CONEP No. 0672006). All subjects gave their written informed consent to participate in this study and it was conducted in accordance with the Helsinki Declaration.

\section{Disabilities of the Arm, Shoulder and Hand (DASH) questionnaire}

The Brazilian version of the DASH questionnaire was used to evaluate the functional status and symptoms of the workers' upper limbs ${ }^{10}$. This self-assessment questionnaire contains 30 questions designed to measure physical function and symptoms, including two items relating to physical function, six items relating to symptoms and three items relating to social function. In addition, there are two modules of four optional items: one for athletes/musicians and another for workers. In this study only the module for workers was used. Each question has five possible responses, ranging from "no difficulty" to "unable to perform activity", and is scored on a one to five-point rating scale. The questionnaire score is calculated by applying established formulae: one for analyzing the first 30 questions and the other used separately 
for the optional modules, as previously described by Hudak et al. ${ }^{9}$.

\section{McGill Pain Questionnaire (MPQ)}

The Brazilian version of the MPQ ${ }^{13}$ was used to evaluate the pain multidimensionally. The original English version of the MPQ contains 78 words, while the Brazilian version contains 68 words because some cultural adaptations were made. As proposed by Melzack ${ }^{11}$, this questionnaire consists of four parts: 1- Pain location; 2- Temporal pattern of the pain; 3- Pain description; and 4- Present Pain Intensity (PPI).

In the first part of the MPQ, the subject is shown anterior and posterior views of the human body and is asked to locate the painful area.

In the second part, information about the temporal pattern of the pain is collected. This includes: when the pain started, whether it is continuous or intermittent, and whether the subject has undergone any kind of intervention to minimize the pain.

The third part is the most original part of the questionnaire. First, the subject is asked to describe the pain spontaneously. Then, a set of 68 possible words to describe the pain is read aloud by the interviewer to the subject. After each word is read out, the subject is given enough time to decide whether or not that word describes his/her pain. The 68 words are divided into four categories: sensory, affective, evaluative and miscellaneous. These four categories are distributed into 20 subcategories that describe different qualities of pain. The subject can choose either one word or no word from each subcategory. The sensory category has ten subcategories (temporal, spatial, punctuate pressure, incisive, constrictive, traction, thermal, brightness, deafness and dullness); the affective category has five subcategories (tiredness, autonomic, fear, punishment and displeasure); the evaluative category has one subcategory (subjective); and the miscellaneous category has four subcategories (pain/ kinetic, sensorial, cold and emotion). Each of the subcategories contains between two and six words that are in order of intensity. The word used to represent the lowest pain intensity is scored as 1 , the next lowest intensity as 2 and so on, as described by Melzack ${ }^{11}$.

The last part of the questionnaire aims to assess the PPI. It indicates the overall pain intensity at the time when the questionnaire is administered. It consists of five descriptors: "sem dor" (no pain); “fraca” (mild); “moderada” (discomforting); “forte” (distressing); “violenta” (horrible) and "insuportável” (excruciating).

On the basis of the MPQ, pain can be quantified in two ways: 1) Number of words chosen: the sum of all the words chosen by the subjects in the 20 subcategories. As the subject can choose at most one word in each subcategory, the maximum number of words that can be chosen is 20; 2) Pain rating index (PRI): this is based on the score from the third part of the questionnaire and is obtained by summing the scores for all the words chosen to describe the pain. The maximum scores for the sensory, affective, evaluative and miscellaneous categories are 34, 17, 5 and 12, respectively.

\section{Statistical analysis}

The results were analyzed using the "Statistica for Windows” software (StatSoft; version 5.5). For the data not normally distributed, the non-parametric Mann-Whitney test was used. The parametric Student's t test was used to analyze the data that presented normal distribution. Statistically significant differences were determined using a level of 5\%. Spearman's correlation test was applied to investigate any correlations between the DASH score and pain duration, and between the DASH score and the amount of time of the workers in the industry. Descriptive analysis was also performed, to assess the frequencies of choosing each word and of reporting each pain level in the PPI.

\section{RESULTS}

There was no difference $(\mathrm{P}>0.05)$ in pain duration between men and women (26.06 \pm 30.47 months and 43.11 \pm 36.48 months, respectively). However, the women were older $(\mathrm{P}<0.05)$ and had worked in the industry for longer than the men $(17.38 \pm 5.73$ years vs. $8.11 \pm 4.14$ years, respectively; $\mathrm{P}<0.05)$.

\section{Disabilities of the Arm, Shoulder and Hand (DASH) questionnaire}

The women presented higher scores $(\mathrm{P}<0.05)$ than the men did, for both DASH overall and DASH work scores (Table 1).

There was a weak correlation, for both men and women, between the DASH score and pain duration ( $r=-0.21$ and $r=0.20 ; \mathrm{P}>0.05)$ and also between the DASH score and length of service $(r=-0.08$ and $r=0.12$, respectively; $P>0.05)$.

\section{McGill Pain Questionnaire (MPQ) \\ Pain Location}

As well as in the shoulder, twelve of the subjects located their pain in the neck and in the upper part of the back. Three of them located the pain in both shoulders. The right shoulder was painful in five women and nine men, and the left shoulder was painful in five women and eleven men. In general, the women presented a greater area of soreness than the men did.

\section{Number of Words Chosen and Pain Description}

Table 2 shows the words most commonly chosen by both male and female workers. Of the 68 possible words, 57 words (83.82 \%) were chosen. 
Table 1. DASH score and DASH work score among workers with shoulder impingement syndrome.

\begin{tabular}{cccc}
\hline & Men $(\mathbf{n}=18)$ & Women $(\mathbf{n}=9)$ & Total $(\mathbf{n}=27)$ \\
\hline $\begin{array}{c}\text { DASH score } \\
\text { (minimum - maximum) }\end{array}$ & $24.30 \pm 15.75$ & $46.97 \pm 14.79^{*}$ & $31.27 \pm 18.54$ \\
& & & \\
DASH work score & $24.65 \pm 17.73$ & $44.53 \pm 19.02^{*}$ & $30.76 \pm 20.07$ \\
$($ minimum - maximum) & $(0.00-56.25)$ & $(12.50-68.75)$ & $(0.00-68.75)$ \\
\hline
\end{tabular}

Results are mean \pm standard deviation. ${ }^{*} \mathrm{P}<0.05$, in comparison with the men.

Table 2. The words in Portuguese most frequently chosen by workers with shoulder impingement syndrome, using the Brazilian version of the McGill Pain Questionnaire.

\begin{tabular}{|c|c|c|c|}
\hline Words chosen & $\operatorname{Men}(n=18)$ & Women $(n=9)$ & Total $(n=27)$ \\
\hline incômoda/annoying & $14(77.78 \%)$ & $9(100.00 \%)$ & $23(85.19 \%)$ \\
\hline que deixa tenso(a)/stressful & $15(83.33 \%)$ & $8(88.89 \%)$ & $23(85.19 \%)$ \\
\hline latejante/throbbing & $12(66.67 \%)$ & $5(55.56 \%)$ & $17(62.96 \%)$ \\
\hline que cresce e diminui/that rises and falls & $13(72.22 \%)$ & $4(44.44 \%)$ & $17(62.96 \%)$ \\
\hline que repuxa/pulling & $12(66.67 \%)$ & $5(55.56 \%)$ & 17 (62.96 \%) \\
\hline dolorida/aching & $13(72.22 \%)$ & $3(33.33 \%)$ & $16(59.26 \%)$ \\
\hline que irradia/shooting & $6(33.33 \%)$ & $8(88.89 \%)$ & $14(51.85 \%)$ \\
\hline castigante/punishing & $10(55.56 \%)$ & $2(22.22 \%)$ & $12(44.44 \%)$ \\
\hline que prende/arresting & 7 (38.89 \%) & $5(55.56 \%)$ & $12(44.44 \%)$ \\
\hline que perturba/disturbing & $8(44.44 \%)$ & $4(44.44 \%)$ & $12(44.44 \%)$ \\
\hline amortecida/dull & $5(27.78 \%)$ & $6(66.67 \%)$ & $11(40.74 \%)$ \\
\hline em cãibra ou cólica/cramping & $8(44.44 \%)$ & $3(33.33 \%)$ & $11(40.74 \%)$ \\
\hline que enfraquece/weakening & $10(55.56 \%)$ & $1(11.11 \%)$ & $11(40.74 \%)$ \\
\hline que esquenta/hot & $6(33.33 \%)$ & $4(44.44 \%)$ & $10(37.00 \%)$ \\
\hline torturante/torturous & $5(27.78 \%)$ & $5(55.56 \%)$ & $10(37.00 \%)$ \\
\hline pica com uma agulhada/pricking & $8(44.44 \%)$ & $2(22.22 \%)$ & $10(37.00 \%)$ \\
\hline como uma ferroada/stinging & $6(33.33 \%)$ & $3(33.33 \%)$ & $9(33.33 \%)$ \\
\hline em formigamento/tingling & $6(33.33 \%)$ & $3(33.33 \%)$ & $9(33.33 \%)$ \\
\hline como uma fisgada/spearing & $4(22.22 \%)$ & $4(44.44 \%)$ & $8(29.63 \%)$ \\
\hline como uma pontada de faca/stabbing & $5(27.78 \%)$ & $3(33.33 \%)$ & $8(29.63 \%)$ \\
\hline chata/troublesome & $7(38.89 \%)$ & $1(11.11 \%)$ & $8(29.63 \%)$ \\
\hline espeta como uma lança/lancinating & $4(22.22 \%)$ & $4(44.44 \%)$ & $8(29.63 \%)$ \\
\hline fria/cool & $2(11.11 \%)$ & $6(66.67 \%)$ & $8(29.63 \%)$ \\
\hline que cansa/tiring & $3(16.67 \%)$ & $5(55.56 \%)$ & $8(29.63 \%)$ \\
\hline que se espalha em círculos/radiating & $6(33.33 \%)$ & $1(11.11 \%)$ & $7(25.93 \%)$ \\
\hline que queima como água quente/scalding & $6(33.33 \%)$ & $1(11.11 \%)$ & $7(25.93 \%)$ \\
\hline de suar frio/makes you break out in a cold sweat & $4(22.22 \%)$ & $3(33.33 \%)$ & $7(25.93 \%)$ \\
\hline
\end{tabular}


The words "pesada” (heavy), "que dá ânsia de vômito” (nauseating) and "que parte ao meio” (splitting) were not chosen to describe the pain by the men, but were used by the women. The female workers did not use the words "fatigante” (fatiguing), "leve” (light), "que salta aqui e ali” (jumping), “inaguentável” (unbearable), “irritante” (irritating), “como um beliscão” (pinching), “de chorar” (agonizing), "gelada” (cold) or "cruel” (cruel).
Generally, the women chose more words (17.00 \pm 2.59$)$ than the men did $(13.33 \pm 3.16)$ and also presented higher mean rating values $(\mathrm{P}<0.05)$ in the sensory and miscellaneous categories (Table 3). Likewise, the highest total pain rating index was presented by the women $(\mathrm{P}<0.05)$.

Table 4 shows the words used by the workers to describe the pain spontaneously. The workers used 25 descriptors, 13 of which are in the Brazilian version of the MPQ.

Table 3. Pain rating index (PRI) in five different categories and present pain intensity (PPI) among workers with shoulder impingement syndrome assessed using the Brazilian version of the McGill Pain Questionnaire.

\begin{tabular}{cccc}
\hline Category (maximum score) & Men (n= 18) & Women $(\mathbf{n}=\mathbf{9})$ & Total (n= 27) \\
\hline Sensory (34) & $14.72 \pm 4.44$ & $20.88 \pm 5.06^{*}$ & $16.77 \pm 5.43$ \\
Affective (17) & $5.50 \pm 2.30$ & $7.11 \pm 3.40$ & $6.03 \pm 2.76$ \\
Evaluative (5) & $2.16 \pm 1.09$ & $2.00 \pm 0.00$ & $2.11 \pm 0.89$ \\
Miscellaneous (12) & $3.55 \pm 1.61$ & $5.22 \pm 1.39^{*}$ & $4.11 \pm 1.71$ \\
Total (68) & $25.94 \pm 6.99$ & $35.22 \pm 7.99^{*}$ & $29.03 \pm 8.46$ \\
& & & \\
PPI & Men (n= 18) & Women (n= 9) & Total (n= 27) \\
0 - Sem dor/no pain & $6(33.33 \%)$ & $0(0.00 \%)$ & $6(22.22 \%)$ \\
1- Fraca/mild & $5(27.78 \%)$ & $2(22.22 \%)$ & $7(25.93 \%)$ \\
2 - Moderada/discomforting & $6(33.33 \%)$ & $5(55.56 \%)$ & $11(40.74 \%)$ \\
3 - Forte/distressing & $0(0.00 \%)$ & $2(22.22 \%)$ & $2(7.41 \%)$ \\
$4-$ Violenta/horrible & $0(0.00 \%)$ & $0(0.00 \%)$ & $0(0.00 \%)$ \\
5 - Insuportável/excruciating & $1(5.56 \%)$ & $0(0.00 \%)$ & $1(3.70 \%)$ \\
\hline
\end{tabular}

$\overline{\text { Results are mean } \pm \text { standard deviation. }{ }^{*} \mathrm{P}<0.05 \text {, in comparison with the men. }}$

Table 4. Portuguese words spontaneously used by male and female workers to describe the pain associated with shoulder impingement syndrome. There are two groups of words: one for words found in the Brazilian version of the McGill Pain Questionnaire (MPQ) and the other for words not listed in this version of the MPQ.

\begin{tabular}{cccc}
\hline Words in the MPQ & Workers n (\%) & Words not listed in the MPQ & Workers n (\%) \\
\hline pica como uma agulhada/ pricking & $7(25.92)$ & forte/ strong & $2(7.40)$ \\
incômoda/ annoying & $6(22.22)$ & aguda/ acute & $2(7.40)$ \\
chata/ troublesome & $6(22.22)$ & prensada/ flattening & $1(3.70)$ \\
como uma pontada de faca/ stabbing & $6(22.22)$ & fina/ thin & $1(3.70)$ \\
latejante/ throbbing & $5(18.51)$ & tem picos/ it has peaks & $1(3.70)$ \\
como uma fisgada/ spearing & $3(11.11)$ & estica/ stretching & $1(3.70)$ \\
em formigamento/ tingling & $3(11.11)$ & puxando/ pulling & $1(3.70)$ \\
que vai e vem/ that comes and goes & $3(11.11)$ & por dentro/ inside & $1(3.70)$ \\
irritante/ irritating & $2(7.40)$ & que desloca o ombro/ sliding & $1(3.70)$ \\
ardida/ smarting & $2(7.40)$ & queima/ burning & $1(3.70)$ \\
adormecida/ numb & $1(3.70)$ & que segura/ holding & $1(3.70)$ \\
enfraquece/ weakening & $1(3.70)$ & uma dor/ a pain & $1(3.70)$ \\
que cansa/ tiring & $1(3.70)$ & & \\
\hline
\end{tabular}




\section{Present Pain Intensity (PPI)}

The PPI results are shown in Table 3. No workers described their pain at the time of answering the questionnaire as "violenta" (horrible). There was a gender difference in the PPI. All the women presented pain at the time of answering the questionnaire, as demonstrated by the fact that level 0 ("sem dor"/no pain) was not chosen by any of the women. Also, the women did not report the levels 4 ("violenta”/horrible) and 5 ("insuportável"/excruciating). The levels 3 ("forte"/distressing) and 4 ("violenta”/horrible) were not chosen by the men.

\section{DISCUSSION}

This is the first study conducted in Brazilian Portuguese that identifies pain descriptors in a group of workers with shoulder impingement syndrome. The results found here may be of particular diagnostic value to clinicians, since verbal language is an important tool in communicating about pain.

It has been proposed that the pain caused by shoulder impingement occurs in the anterosuperior region of the shoulder ${ }^{3}$. However, a recent study reported that shoulder impingement can also present as neck pain ${ }^{21}$. Those authors described neck pain in the area of the superomedial border of the scapula. Our results concerning pain location in workers with shoulder impingement are in accordance with these two previous reports. The pain was located in the anterosuperior region of the shoulder, in the neck and in the upper part of the back.

In our study the female workers presented higher DASH scores (mean score of 46) than the male workers (mean score of 24), which suggests that the physical function of the women is more impaired. Recently, the Swedish version of the DASH questionnaire was used to evaluate of the satisfation subacromial impingement patients who were treated with arthroscopic subacromial decompression ${ }^{8}$. A high level of satisfaction six months after surgery was reported, with no gender-related differences regarding the absolute change in DASH scores. However, that study did not report DASH scores separately for males and females, before and after surgery separately. The patients had a mean age of 49 years and a mean score of 42 points before the surgery. In our study, the subjects were younger (mean age of 33 years) and presented a mean score of 31 points. Another study using the English version of DASH showed higher scores among older patients than among younger ones ${ }^{22}$. In our study, the women were older and presented more years of work than the men.

In the present study, it was also possible to note a gender difference in the number of words chosen to describe the pain and in the total MPQ pain rating index. The women in this study used more words and presented higher total pain index values. One previous report also found that employed women are more likely than men are to report upper limb disorders ${ }^{23}$. In addition to being caused by age and the amount of time at work, this gender difference may be due to the persistent gender imbalance in domestic work ${ }^{23}$. Our study confirms this hypothesis because, during the interviews with the workers, most of the women complained of pain while doing housework such as hanging clothes on a clothesline.

Other studies have also demonstrated that women are more sensitive to pain and more inclined to report greater pain in relation to experimentally controlled muscle pain conditions $^{24,25}$. On the other hand, no gender differences have been found in relation to the development of delayed-onset muscle soreness in the neck and shoulder muscles ${ }^{26}$.

The Brazilian version of the MPQ used in this study was previously applied to women with work-related musculoskeletal disorders ${ }^{27}$. In that study, the women most frequently selected the words "latejante" (throbbing), "que irradia" (shooting), "que queima como fogo” (burning) and "em formigamento" (tingling) to describe their pain. In our study, three of these words were among the most chosen: "latejante" (throbbing), "que irradia” (shooting) and "em formigamento" (tingling).

Male industry butchers with chronic neck-shoulder pain were evaluated during standardized low load repetitive work and were asked to complete the Danish version of the $\mathrm{MPQ}^{28}$. Rotator cuff syndrome was confirmed in 9 of the 12 workers and the most often selected words to qualify their usual pain were "shooting”, "hurting” and "annoying”. Note that in our study the words "que irradia" (shooting) and "incômoda" (annoying) were also among the most chosen words identified by the workers using the Brazilian version of the MPQ.

Many different symptoms may be characterized or are strongly correlated with certain pain describing adjectives ${ }^{29}$. Therefore, studies that investigate pain descriptors are interesting to ascertain whether certain pain descriptive words are common to subjects with a given condition. Because the description of the pain is linked to the subjects' respective linguistic, cultural, socioeconomic and educational backgrounds, as well as individual pain experiences, it is important that the patients' backgrounds be considered when assessing pain. The spontaneous complaints presented in Table 4 show the importance of the cultural adaptation. As this study evaluated workers of only one city in Brazil, the pain descriptive words may not represent those used in the whole country. In future studies, it would be interesting to evaluate the descriptors of pain used by workers with shoulder impingement in other regions of Brazil and in other countries where the Portuguese is spoken.

\section{CONCLUSIONS}

The results obtained from a group of Brazilian workers with shoulder impingement reveal the most commonly used descriptors for shoulder pain. Further, the results indicate that female workers are more likely to report physical disability 
and pain than male workers are. Taken together, these observations indicate that the DASH and McGill pain questionnaires are important and helpful tools in clinically evaluating shoulder impingement syndrome.

Acknowledgments: Paula Rezende Camargo and Melina Nevoeiro Haik received research fellowships from CAPES and FAPESP (Brazilian funding agencies), respectively. The authors are deeply grateful to the workers who participated in this study, as well as to the industry for allowing the study to be performed. We also want to thank Dr. Lazarus Jason Deiner for reviewing the English.

\section{REFERENCES}

1. Neer CS. Anterior acromioplasty for the chronic impingement syndrome in the shoulder: a preliminary report. J Bone Joint Surg Am. 1972;54-A:41-50.

2. Walther M, Werner A, Stahlschmidt T, Woelfel R, Gohlke F. The subacromial impingement syndrome of the shoulder treated by conventional physiotherapy, self-training, and a shoulder brace: Results of a prospective, randomized study. J Shoulder Elbow Surg. 2004;13:417-23.

3. Bigliani LU, Levine WN. Current concepts review: Subacromial impingement syndrome. J Bone Joint Surg Am. 1997; 79-A:1854-8.

4. Roddey TS, Olson SL, Cook KF, Gartsman GM, Hanten W. Comparison of the University of California - Los Angeles Shoulder Scale and the Simple Shoulder Test with the Shoulder Pain and Disability Index: single administration reliability and validity. Phys Ther. 2000;8:759-68.

5. Cloke DJ, Lynn SE, Watson H, Steen IN, Pudy S, Williams JR. A comparison of functional, patient-based scores in subacromial impingement. J Shoulder Elbow Surg. 2005;14:380-4.

6. Leclerc A, Chastang JF, Niedhammer I, Landre MF, Roquelaure Y. Incidence of shoulder pain in repetitive work. Occup Environ Med. 2004;61:39-44.

7. Ludewig PM, Borstad JD. Effects of a home exercise programme on shoulder pain and functional status in construction workers. Occup Environ Med. 2003;60:841-9.

8. Bengtsson M, Lunsjö K, Hermodsson Y, Nordqvist A, AbuZidan FM. High patient satisfaction after arthroscopic subacromial decompression for shoulder impingement - A prospective study of 50 patients. Acta Orthop. 2006;77: 138-42.

9. Hudak PL, Amadio PC, Bombardier C. Development of an upper extremity outcome measure: the DASH. Am J Ind Med. 1996;29:602-6.

10. Orfale AG, Araújo PMP, Ferraz MB, Natour J. Translation into Brazilian Portuguese, cultural adaptation and evaluation of the reliability of the disabilities of the arm, shoulder and hand questionnaire. Braz J Med Biol Res. 2005;38:293-302.

11. Melzack R. The McGill Pain Questionnaire major properties and scoring methods. Pain. 1975;1:277-99.
12. Pimenta CAM, Teixeira MJ. McGill pain questionnaire: Purpose of adaptation to the Portuguese language. J São Paulo School Nurs. 1996;30:473-83.

13. Castro CES. Formulação linguística da dor: versão brasileira do questionário McGill de dor [Dissertação]. São Carlos (SP): UFSCar; 1999.

14. Mendonça Jr HP, Assunção AA. Association between shoulder diseases and work: a brief review. Rev Bras Epidemiol. 2005; 8:167-76.

15. Hawkins RJ, Kennedy JC. Impingement syndrome in athletes. Am J Sports Med. 1980;8:151-8.

16. Jobe FW, Moynes DR. Delineation of diagnostic criteria and a rehabilitation program for rotator cuff injuries. Am J Sports Med. 1982;10:336-9.

17. Calis M, Akgun K, Birtane M, Karacan I, Calis H, Tuzun F. Diagnostic values of clinical diagnostic tests in subacromial impingement syndrome. Ann Rheum Dis. 2000;59:44-7.

18. Gerber C, Krushell RJ. Isolated rupture of the subscapularis tendon. J Bone Joint Surg. 1991;73-B:389-94.

19. Yergason RM. Supination sign. J Bone Joint Surg. 1931;13:160.

20. Neer CS. Impingement lesions. Clin Orthop. 1983;173:70-7.

21. Gorski JM, Schwartz LH. Shoulder impingement presenting as neck pain. J Bone Joint Surg. 2003;85-A:635-8.

22. Hunsaker FG, Cioffy DA, Amadio PC, Wright JG, Cauglin B. The American academy of orthopaedic surgeons outcomes instruments: normative values from the general population. J Bone Joint Surg Am. 2002;84:208-15.

23. Strazdins L, Bammer G. Women, work and musculoskeletal health. Soc Sci Med. 2004;58:997-1005.

24. Riley JL, Robinson ME, Wise EA, Myers CD, Fillingim RB. Sex differences in the perception of noxious experimental stimuli: a meta-analysis. Pain. 1998;74:181-7.

25. Ge HY, Madeleine P, Arendt-Nielsen L. Sex differences in temporal characteristics of descending inhibitory control: an evaluation using repeated bilateral experimental induction of muscle pain. Pain. 2004;110:72-8.

26. Nie H, Kawczynski A, Madeleine P, Arendt-Nielsen L. Delayed onset muscle soreness in neck/shoulder muscles. Eur J Pain. 2005;9:653-60.

27. Landgraf JF, Zanichelli K, Chiappa L, Castro CES, Salvini TF. The effect of the kinesiotherapy and of the massage in the pain of women with WRMD grade III. Braz J Phys Ther. 2002;6: 87-96.

28. Madeleine P, Lundager B, Voigt M, Arendt-Nielsen L. Sensory manifestations in experimental and work-related chronic neckshoulder pain. Eur J Pain. 1998;2:251-60.

29. Van Wijk AJ, Hoogstraten J. Paired comparisons of sensory pain adjectives. Eur J Pain. 2004;8:293-7. 